\title{
Ensiling of Soybean Curd Residue and Wet Brewers Grains With or Without Other Feeds as a Total Mixed Ration
}

\author{
F. Wang and N. Nishino ${ }^{1}$ \\ Department of Biomolecular Science, Graduate School of Natural Science and Technology, Okayama University, Okayama 700-8530, Japan
}

\begin{abstract}
Wet brewers grains and soybean curd residue were stored in laboratory-scale silos without (BG and SC silages, respectively) or with other ingredients as total mixed rations (BGT and SCT silages, respectively). Silages were opened after 14 and $56 \mathrm{~d}$, and microbial counts, fermentation products, and aerobic stability were determined. Denaturing gradient gel electrophoresis was carried out to examine bacterial communities, and several bacteria that appeared to be involved in fermentation were identified. Lactic acid content was greater in SCT than in BGT silage, but lower in SC than in BG silage. Ethanol content was greater in BG than in $\mathrm{SC}$ regardless of silage type. Aerobic deterioration occurred promptly in ensiling materials (nonensiled by-products and total mixed ration mixtures) and in silages stored alone; however, SCT and BGT silages resisted deterioration and no heating was found for more than $5.5 \mathrm{~d}$ regardless of storage period. Silages were stable even with high yeast populations at silo opening, whereas prolonged ensiling decreased yeast counts in the 2 total mixed ration silages. The denaturing gradient gel electrophoresis profiles appeared similar between SCT and BGT silages but not between SC and BG silages. Weissella spp. and Lactobacillus brevis were common in aerobically stable SCT and BGT silages, and Lactobacillus buchneri was detected only in BGT silage. Both L. brevis and L. buchneri were found in silage but not in ensiling materials. Several other lactic acid bacteria were also identified in SCT and BGT silages, but did not appear to be related to fermentation and aerobic stability.
\end{abstract}

Key words: by-product, denaturing gradient gel electrophoresis, silage, total mixed ration

\section{INTRODUCTION}

Because of economic and environmental concerns, the utilization of food by-products is expected to increase

Received November 1, 2007.

Accepted February 10, 2008.

${ }^{1}$ Corresponding author: j1oufeed@cc.okayama-u.ac.jp and to become more efficient. The Japanese government legislated a Food Recycling Act in 2001, and has promoted the "3Rs" (i.e., reduce, reuse, and recycle) of organic resources generated by the food industries. Many food by-products are high in moisture content and are thus often stored by ensiling to avoid the energy costs of drying. Although some wet by-products can be ensiled without any additives (Katayama, 2001; Osaka, 2001), much cost would be wasted on transporting water rather than nutrients. Therefore, a practice in Japan is to mix wet by-products with dry feeds to prepare low-moisture TMR silage (Abe, 2000; Imai, 2001). Wet brewers grains (BG) and soybean curd residue (SC) are often used as the main ingredients, and various feedstuffs such as grass hay, legume hay, cracked corn, soybean meal, and wheat bran are added in lower proportions (Abe, 2000). More than 10 ingredients are usually formulated to create a TMR silage, which is stored in thick polyethylene bags after vacuum packing. The $\mathrm{DM}, \mathrm{CP}$, and total digestible nutrient contents are 50 to $60 \%, 16$ to $18 \%$ of $\mathrm{DM}$, and 72 to $74 \%$ of $\mathrm{DM}$, respectively, and silages are commercialized in the form of transportable (300 to $400 \mathrm{~kg}$ ) bag silos (Nishino, 2006). Because silage manufacturers do not have enough space available to store a large numbers of bags, a short ensiling period is preferred.

Our previous study (Nishino et al., 2003a) showed that although deterioration occurred promptly (within $2 \mathrm{~d}$ after silo opening) when BG was ensiled alone, no heating was shown for $7 \mathrm{~d}$ when BG was stored as a TMR silage. We isolated Lactobacillus buchneri from stable TMR silage as a predominant lactic acid bacterium (LAB), and then found that the 1,2-propanediolproducing $\mathrm{LAB}$ can suppress aerobic deterioration of corn and grass silages (Nishino et al., 2003b, 2004; Nishino and Touno, 2005). Although the reason why $L$. buchneri predominated during fermentation is unknown, our findings suggest that $L$. buchneri may account for the stability of BG-containing TMR silage. Interestingly, deterioration was suppressed even with yeast counts $>10^{6} \mathrm{cfu} / \mathrm{g}$ at silo opening (Nishino et al., 2004; Nishino and Hattori, 2007; Wang and Nishino, 2008), despite the fact that silage with a high yeast 
population $\left(>10^{5} \mathrm{cfu} / \mathrm{g}\right)$ is prone to deteriorate on exposure to air (McDonald et al., 1991). Yeast numbers decreased to below detectable levels when ensiling was prolonged, indicating that the stability of TMR silage can be further improved by a lack of undesirable microorganisms.

Previously, we examined the properties of TMR silage by using only BG as a wet by-product (Nishino et al., 2004; Nishino and Hattori, 2007; Wang and Nishino, 2008), although about 0.7 times more SC than BG is produced annually in Japan (Abe, 2000). Wet BG is a residue obtained after extracting wort from mashed malted grains, and SC is a pulp obtained after straining soy milk. The DM and CP contents are 75 to $80 \%$ and 26 to $27 \%$ of DM, respectively, in both by-products (Abe, 2000; Imai, 2001). Farmers and silage manufacturers have recognized a similar stability in SC-containing TMR silage; however, no experiments have been done to investigate whether L. buchneri would predominate during fermentation and produce 1,2-propanediol. It has been shown that $\mathrm{SC}$ is more difficult to ensile alone than BG, because aerobic bacteria may grow fast and spoilage would occur soon after disposal (Niwa, 2001).

The aim of present experiments was to evaluate the fermentation and aerobic stability of TMR silage prepared with BG and SC as the main ingredients. Microorganisms involved in fermentation and aerobic stability were examined by PCR-denaturing gradient gel electrophoresis (PCR-DGGE), and several bacteria were identified by $16 \mathrm{~S}$ rDNA sequence.

\section{MATERIALS AND METHODS}

\section{Ensiling}

Two experiments (Exp.) were performed (Table 1). In Exp. 1, only TMR silage was prepared with SC or BG as a main ingredient (SCT and BGT silages). In Exp. 2, silages were prepared with $\mathrm{SC}$ and $\mathrm{BG}$ alone (SC and BG silages) or with other feeds (SCT and BGT silages). The TMR mixtures were formulated with wet by-products (SC or BG) at 50\% on a fresh weight basis, and with alfalfa hay, sudangrass hay, cracked corn, wheat bran, beet pulp, soybean meal, and molasses at lower proportions. Targeted DM and total digestible nutrients were 55 and $74 \%$ of DM, respectively. The TMR were stored in vacuum-packed plastic pouches. Fresh by-products or TMR mixtures (300 g) were put into a pouch, and an airtight silo was prepared by using a vacuum sealer. Silages were made in triplicate and stored at ambient temperature (Exp. 1) or at $25^{\circ} \mathrm{C}$ (Exp. 2) for 14 and $56 \mathrm{~d}$, respectively.

\section{Aerobic Stability Test}

After silage was completely opened, half the contents $(150 \mathrm{~g})$ were put into polyethylene bottles $(500 \mathrm{~mL})$ without compaction. The top of the bottle was kept uncovered and exposed to air for $7 \mathrm{~d}$ in a room maintained at $25^{\circ} \mathrm{C}$. A conventional thermometer was placed in the center of the silage, and the temperature was recorded at 12-h intervals. Aerobic deterioration was judged to have started when the temperature reached $2^{\circ} \mathrm{C}$ above the surrounding temperature.

\section{Chemical and Microbial Analyses}

The DM contents were determined by freeze-drying. Silage $\mathrm{pH}$, lactic acid, short-chain fatty acids, and alcohols were determined on water extracts (Nishino et al., 2004). Analysis of volatile fermentation products was performed by GC (GC-14A, Shimadzu, Kyoto, Japan) fitted with a glass capillary column $(15 \mathrm{~m} \times 0.53 \mathrm{~mm})$ coated with polyethylene glycol terephthalic acid modified (TC-FFAP, GL Sciences, Tokyo, Japan). The temperature of column oven was programmed at $80^{\circ} \mathrm{C}$ for the first $2 \mathrm{~min}$ and thereafter increased to $200^{\circ} \mathrm{C}$ at a rate of $10^{\circ} \mathrm{C} / \mathrm{min}$. The numbers of $\mathrm{LAB}$ and yeasts were counted using de Man, Rogosa, and Sharpe agar, and potato dextrose agar, respectively. The $\mathrm{pH}$ of potato dextrose agar was adjusted to 3.5 by adding sterilized lactic acid solution after autoclaving. The serially diluted plates of $\mathrm{LAB}$ and yeasts were incubated at $30^{\circ} \mathrm{C}$ for $3 \mathrm{~d}$.

\section{DGGE}

A frozen sample was thawed and added with 40 times the volume of sterilized PBS. Extraction was made by vigorous shaking for $10 \mathrm{~min}$ at ambient temperature, and microbial pellets were obtained by centrifugation at $8,000 \times g$ for $15 \mathrm{~min}$. Bacterial DNA was purified using a commercial kit (DNeasy Tissue Kit, Qiagen, Germantown, MD) according to the manufacturer's recommendation.

Polymerase chain reaction was carried out to amplify a variable region (V3 region) of the bacterial 16S rDNA with the GC-clamp forward primer GC357f (5'-CGCC CGCCGCGCGCGGCGGGCGGGGCGGGGGCACGG GGGGCCTACGGGAGGCAGCAG-3') and the reverse primer 517r (5'-ATTACCGCGGCTGCTGG-3'). Amplification was done in a standard reaction mixture containing $25 \mathrm{~m} M$ Tris (hydroxymethyl) methyl aminopropane sulfonic acid ( $\mathrm{pH}$ 9.3), $50 \mathrm{mM} \mathrm{KCl,} 2.0 \mathrm{mM}$ $\mathrm{MgCl}_{2}, 0.2 \mathrm{~m} M \mathrm{dNTP}, 2.5 \mathrm{U}$ of Taq polymerase, 1.0 $\mathrm{m} M$ each primer, and the DNA template. The PCR was run with an initial denaturation at $95^{\circ} \mathrm{C}$ for $10 \mathrm{~min}$, and 30 cycles of denaturation at $93^{\circ} \mathrm{C}$ for $30 \mathrm{~s}$, annealing 
WANG AND NISHINO

Table 1. Ingredients and composition of wet by-products and their TMR mixtures

\begin{tabular}{|c|c|c|c|c|c|c|}
\hline \multirow[b]{3}{*}{ Item } & \multicolumn{6}{|c|}{ Treatment $^{1}$} \\
\hline & \multicolumn{2}{|c|}{ Experiment 1} & \multicolumn{4}{|c|}{ Experiment 2} \\
\hline & SCT & BGT & $\mathrm{SC}$ & BG & $\mathrm{SCT}$ & BGT \\
\hline \multicolumn{7}{|l|}{ Ingredient (\%) } \\
\hline Soybean curd residue & 50 & & 100 & & 50 & \\
\hline Wet brewers grains & & 50 & & 100 & & 50 \\
\hline Alfalfa hay & 5 & 5 & & & 5 & 5 \\
\hline Sudangrass hay & 5 & 5 & & & 5 & 5 \\
\hline Cracked corn & 10 & 10 & & & 10 & 10 \\
\hline Wheat bran & 10 & 10 & & & 10 & 10 \\
\hline Soybean meal & 2 & 2 & & & 2 & 2 \\
\hline Dried beet pulp & 10 & 10 & & & 10 & 10 \\
\hline Molasses & 8 & 8 & & & 8 & 8 \\
\hline \multicolumn{7}{|l|}{ Composition } \\
\hline $\mathrm{DM}(\%)$ & 55.4 & 58.9 & 23.3 & 25.3 & 55.6 & 57.5 \\
\hline $\mathrm{CP}(\%$ of $\mathrm{DM})$ & 15.3 & 14.6 & 24.9 & 27.0 & 14.6 & 13.4 \\
\hline $\mathrm{WSC}^{2}(\%$ of $\mathrm{DM})$ & 6.37 & 6.94 & 3.36 & 4.74 & 6.69 & 8.34 \\
\hline $\mathrm{pH}$ & 5.14 & 5.19 & 6.68 & 4.22 & 5.58 & 5.19 \\
\hline Lactic acid bacteria (log cfu/g) & 8.65 & 6.30 & $<2.00$ & 6.91 & 3.94 & 6.36 \\
\hline Yeasts (log cfu/g) & 3.69 & 3.45 & $<2.00$ & 3.79 & 3.26 & $<2.00$ \\
\hline
\end{tabular}

at $65^{\circ} \mathrm{C}$ (first 10 cycles), $60^{\circ} \mathrm{C}$ (second 10 cycles), or $55^{\circ} \mathrm{C}$ (last 10 cycles) for $30 \mathrm{~s}$, and extension at $72^{\circ} \mathrm{C}$ for 1 min, with a final extension at $72^{\circ} \mathrm{C}$ for 5 min (Pedro et al., 2001). The reaction was conducted in a PCR thermal cycler (Dice, Takara Bio Inc., Shiga, Japan).

The GC-clamp PCR products were separated according to their sequences with a DCode Universal Mutation System (Bio-Rad Ltd., Tokyo, Japan). The samples were applied directly onto $10 \%$ (wt/vol) polyacrylamide gels in a running buffer containing $20 \mathrm{~m} M$ Trisacetate and $0.5 \mathrm{~m} M$ EDTA-2Na ( $\mathrm{pH}$ 8.5). The gels were prepared with a denaturing gradient from 25 to $50 \%$ of urea and formamide. Electrophoresis was conducted at a constant voltage of $150 \mathrm{~V}$ for $12 \mathrm{~h}$ at $60^{\circ} \mathrm{C}$. After electrophoresis, gels were stained with SYBR Green (Cambrex Bio Science Inc., Rockland, ME) and photographed under UV illumination.

\section{Sequence Analyses of DNA Bands}

Bands of interest were excised from DGGE gels and the pieces were soaked in $10 \mu \mathrm{L}$ of sterilized water to allow diffusion of DNA. Extracted DNA was amplified by PCR using $357 \mathrm{f}$ (without GC-clamp) and 517r primers, and then PCR products were purified using a commercial cleanup kit (GeneClean Kit, Qbiogene, Carlsbad, CA). The sequencing reaction was carried out using the Big Dye Terminator v3.1 Cycle Sequencing Kit (Applied Biosystems, Foster City, CA), and DNA base sequences were analyzed by using an ABI PRISM 310 sequencer (Applied Biosystems). Searches in the Gen-
Bank database with the BLAST program were performed to determine the closest relatives of partial $16 \mathrm{~S}$ rDNA sequences. Percentage identities ranged from 86 to $100 \%$.

\section{Statistical Analyses}

In Exp. 1, data were subjected to ANOVA and differences between means were assessed by Student's $t$-test. In Exp. 2, a 2-way ANOVA was applied with by-product source and silage type as the main factors. These statistical analyses were performed by using JMP IN software (ver. 5.1.2, SAS Institute, Tokyo, Japan).

\section{RESULTS}

The DM contents of fresh BG and SC were as low as $25 \%$ (Table 1). Although the wet by-products were obtained soon after their disposal from factories, they contained a small amount of lactic acid, and the $\mathrm{pH}$ of $\mathrm{BG}$ product was reduced to 4.2. The LAB and yeasts counts were $10^{7}$ and $10^{4} \mathrm{cfu} / \mathrm{g}$, respectively, in BG material, whereas their counts were below detectable levels in SC product. The DM contents were more than $55 \%$ in all TMR materials. In all TMR mixtures, the $\mathrm{pH}$ was greater than 5.0, and LAB and yeasts counts were $10^{6}$ and $10^{3}$ to $10^{4} \mathrm{cfu} / \mathrm{g}$, respectively.

Lactic acid was the main fermentation product in both SCT and BGT silages in Exp. 1 (Table 2). Lactic acid content was greater in SCT than BGT silage regardless of storage period, and the content increased 
Table 2. Chemical and microbial composition of TMR silages containing soybean curd residue and brewers grains (experiment 1 )

\begin{tabular}{|c|c|c|c|c|}
\hline \multirow[b]{2}{*}{ Item } & \multicolumn{2}{|c|}{ Treatment $^{1}$} & \multirow[b]{2}{*}{ SEM } & \multirow[b]{2}{*}{$t$-tes } \\
\hline & $\mathrm{SCT}$ & BGT & & \\
\hline \multicolumn{5}{|l|}{ Ensiling for $14 \mathrm{~d}$} \\
\hline Lactic acid (\%) & $\begin{array}{l}4.00 \\
1.90\end{array}$ & $\begin{array}{l}4.29 \\
1.15\end{array}$ & 0.06 & $* *$ \\
\hline Acetic acid (\%) & 1.17 & 1.04 & 0.07 & NS \\
\hline Propionic acid (\%) & 0.01 & 0.02 & 0.00 & $* *$ \\
\hline Butyric acid (\%) & 0.01 & 0.01 & 0.00 & NS \\
\hline Undissociated $\operatorname{acids}^{2}(\%)$ & 1.71 & 1.10 & 0.06 & $* *$ \\
\hline Ethanol (\%) & 0.07 & 0.88 & 0.04 & ** \\
\hline 1,2-Propanediol (\%) & 0.00 & 0.00 & - & - \\
\hline Lactic acid bacteria (log cfu/g) & 8.68 & 8.28 & 0.03 & ** \\
\hline Yeasts (log cfu/g) & 2.57 & 6.10 & 0.49 & $* *$ \\
\hline \multicolumn{4}{|l|}{ Ensiling for $56 \mathrm{~d}$} & $* *$ \\
\hline Lactic acid $(\%)$ & 2.53 & 1.56 & 0.13 & $* *$ \\
\hline Acetic acid (\%) & 1.08 & 0.72 & 0.13 & NS \\
\hline Propionic acid (\%) & 0.00 & 0.01 & 0.00 & NS \\
\hline Butyric acid (\%) & 0.00 & 0.00 & - & - \\
\hline Undissociated acids ${ }^{2}(\%)$ & 2.05 & 1.23 & 0.17 & $*$ \\
\hline Ethanol (\%) & 0.03 & 0.73 & 0.13 & $*$ \\
\hline 1,2-Propanediol (\%) & 0.01 & 0.12 & 0.01 & ** \\
\hline Lactic acid bacteria (log cfu/g) & 7.22 & 7.30 & 0.28 & NS \\
\hline Yeasts (log cfu/g) & $<2.00$ & 2.47 & - & - \\
\hline
\end{tabular}

${ }^{1} \mathrm{SCT}=\mathrm{TMR}$ containing soybean curd residue; BGT = TMR containing brewers grains.

${ }^{2}$ Sum of undissociated lactic acid and VFA.

$* P<0.05 ; * * P<0.01 ; \mathrm{NS}=P>0.05$.

with prolonged ensiling. Ethanol content was greater in BGT than in SCT silage, and the production in 56d BGT silage was comparable to acetic acid. 1,2-Propanediol was found in both 56-d silages, but only at trace levels $(0.01 \%)$ in SCT silage. About $10^{8}$ and $10^{7}$ $\mathrm{cfu} / \mathrm{g}$ of LAB were present in 14- and 56-d silages, respectively, regardless of by-product type. Although yeast counts exceeded $10^{6} \mathrm{cfu} / \mathrm{g}$ in 14-d BGT silage, the numbers decreased to a nearly undetectable level $\left(10^{2}\right.$ $\mathrm{cfu} / \mathrm{g}$ ) when ensiling was prolonged for $56 \mathrm{~d}$. Yeast counts were less than $10^{3} \mathrm{cfu} / \mathrm{g}$ in 14-d SCT silage, and yeasts were undetectable in 56-d silage.

When BG was ensiled alone, lactic acid was produced rapidly, reducing $\mathrm{pH}$ to below 3.5 after $14 \mathrm{~d}$ (Table 3). Lactic acid production was less in SC silage, and $\mathrm{pH}$ remained at 4.4 after $14 \mathrm{~d}$ of storage. Prolonged ensiling increased acetic acid content, and $\mathrm{pH}$ increased to 4.6 in 56-d SC silage. Ethanol production was greater in BG than in SC silage. Fermentation of TMR silage in Exp. 2 was similar to that in Exp. 1; lactic acid content was greater in SCT than in BGT silage, but the opposite result was shown for ethanol content. Greater ethanol content in 14-d BGT silage was associated with a higher yeast count. Prolonged ensiling decreased yeast counts, more so in SCT than in BGT silage. An interesting observation was that lactic acid production was greater in BG when ensiled alone, whereas production was greater in SC when ensiled as a TMR. 1,2-Propanediol content was low in Exp. 2, and the maximum was $0.03 \%$ in 56-d BGT silage.

Aerobic deterioration occurred within $2 \mathrm{~d}$ in materials and in silages stored alone (Figure 1). One exception was 56-d SC silage, in which heating was detected after $4 \mathrm{~d}$ in the presence of air. The TMR silages resisted deterioration for more than $5.5 \mathrm{~d}$ regardless of by-product type and storage period. Ensiling for $56 \mathrm{~d}$ enhanced stability, and 14-d SCT and BGT silages appeared relatively stable.

In Exp. 2, Weissella spp. and Lactobacillus brevis were common in SCT and BGT silages (Figure 2). Weissella spp. were also found in SCT material, whereas a corresponding DNA band was not found in BGT material. Streptococcus spp. were detected in SCT material and appeared to survive ensiling for $56 \mathrm{~d}$. In contrast, Lactobacillus fermentum in SCT material did not exist after $14 \mathrm{~d}$ of storage, and Lactobacillus plantarum in BGT material also disappeared during fermentation. Lactobacillus brevis was not present in either SCT or BGT material, but was detected after $14 \mathrm{~d}$ of storage in both TMR silages. Lactobacillus buchneri was also detected when BGT was ensiled, but the bacterium was not found in TMR material or in SCT silages.

Weissella spp. and L. brevis were also common in SCT and BGT silages in Exp. 2. Lactobacillus brevis was not detected in any of the materials, and was detected only in TMR silages. Lactobacillus plantarum was found in BG and BGT materials, and appeared to survive only when BG was ensiled alone. Similar to Exp. 1, L. buchneri was not detected in either BG or BGT material, but was detected after $14 \mathrm{~d}$ of storage in both BG and BGT silages. Streptococcus spp. were found only in SC silage, whereas Pediococcus acidilactici was detected in BG and BGT silages.

\section{DISCUSSION}

Lactic acid production was low in SC silage and the content decreased with prolonged ensiling (Exp. 2). Lactic acid content was also lower in BG silage after 56 than after $14 \mathrm{~d}$ of storage. It has been shown that good preservation is difficult to obtain with SC ensiled alone (Niwa, 2001), and lactic acid can predominate in BG silage, especially with a short storage period (Schneider et al., 1995; Nishino et al., 2003a). A reduction in lactic acid content coupled with an increase in acetic acid content was shown in SC and BG silages, suggesting that L. plantarum or L. buchneri metabolism was activated. Lactobacillus plantarum and L. buchneri are known to produce acetic acid from lactic acid under anaerobic conditions (Lindgren et al., 1990; Oude Elferink et al., 2001), and the 2 species were detected in BG 
Table 3. Chemical and microbial composition of wet by-products and their TMR silages prepared with soybean curd residue and brewers grains (experiment 2)

\begin{tabular}{|c|c|c|c|c|c|c|c|c|}
\hline \multirow[b]{2}{*}{ Item } & \multicolumn{4}{|c|}{ Treatment ${ }^{1}$} & \multirow[b]{2}{*}{ SEM } & \multicolumn{3}{|c|}{ Analysis of variance ${ }^{2}$} \\
\hline & $\mathrm{SC}$ & BG & $\mathrm{SCT}$ & BGT & & $\mathrm{M}$ & $\mathrm{S}$ & $\mathrm{M} \times \mathrm{S}$ \\
\hline \multicolumn{9}{|l|}{ Ensiling for $14 \mathrm{~d}$} \\
\hline $\mathrm{pH}$ & 4.38 & 3.49 & 3.83 & 3.98 & 0.02 & $* *$ & NS & $* *$ \\
\hline Lactic acid (\%) & 0.52 & 1.01 & 2.23 & 1.57 & 0.08 & NS & $* *$ & ** \\
\hline Acetic acid (\%) & 0.19 & 0.09 & 0.62 & 0.50 & 0.04 & $*$ & $* *$ & NS \\
\hline Propionic acid (\%) & 0.00 & 0.00 & 0.01 & 0.00 & 0.01 & NS & NS & NS \\
\hline Butyric acid (\%) & 0.00 & 0.00 & 0.00 & 0.00 & - & - & - & - \\
\hline 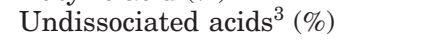 & 0.26 & 0.80 & 1.71 & 1.10 & 0.05 & NS & $* *$ & $* *$ \\
\hline Ethanol (\%) & 0.05 & 0.72 & 0.22 & 1.41 & 0.05 & $* *$ & $* *$ & $* *$ \\
\hline 1,2-Propanediol (\%) & 0.00 & 0.00 & 0.00 & 0.01 & 0.00 & NS & NS & NS \\
\hline Lactic acid bacteria (log cfu/g) & 8.30 & 6.94 & 7.94 & 7.93 & 0.10 & $* *$ & $*$ & $* *$ \\
\hline Yeasts (log cfu/g) & 5.49 & 5.92 & 3.92 & 5.56 & 0.43 & $* *$ & NS & NS \\
\hline \multicolumn{9}{|l|}{ Ensiling for $56 \mathrm{~d}$} \\
\hline $\mathrm{pH}$ & 4.60 & 3.14 & 3.90 & 4.00 & 0.05 & $* *$ & NS & $* *$ \\
\hline Lactic acid (\%) & 0.22 & 0.69 & 1.32 & 1.12 & 0.05 & $*$ & $* *$ & $* *$ \\
\hline Acetic acid (\%) & 0.50 & 0.25 & 0.31 & 0.45 & 0.12 & NS & NS & NS \\
\hline Propionic acid (\%) & 0.12 & 0.01 & 0.02 & 0.01 & 0.01 & $* *$ & $* *$ & $* *$ \\
\hline Butyric acid (\%) & 0.00 & 0.10 & 0.00 & 0.00 & 0.08 & NS & NS & NS \\
\hline Undissociated $\operatorname{acids}^{3}(\%)$ & 0.32 & 0.73 & 0.90 & 0.85 & 0.11 & NS & $*$ & NS \\
\hline Ethanol (\%) & 0.21 & 0.55 & 0.42 & 0.72 & 0.11 & $*$ & NS & NS \\
\hline 1,2-Propanediol (\%) & 0.02 & 0.00 & 0.00 & 0.03 & 0.00 & $*$ & $*$ & $* *$ \\
\hline Lactic acid bacteria (log cfu/g) & 8.24 & 7.08 & 4.78 & 5.95 & 0.29 & NS & $* *$ & $* *$ \\
\hline Yeasts (log $\mathrm{cfu} / \mathrm{g})$ & $<2.00$ & 5.20 & $<2.00$ & 2.46 & - & - & - & - \\
\hline
\end{tabular}

${ }^{1} \mathrm{SC}=$ soybean curd residue; $\mathrm{BG}=$ brewers grains; $\mathrm{SCT}=\mathrm{TMR}$ containing $\mathrm{SC} ; \mathrm{BGT}=\mathrm{TMR}$ containing BG.

${ }^{2} \mathrm{M}=$ effect of by-product material; $\mathrm{S}$ = effect of storage method.

${ }^{3}$ Sum of undissociated lactic acid and VFA.

$* P<0.05 ; * * P 0.01 ; \mathrm{NS}=P>0.05$.

silage. Secondary fermentation associated with clostridia could also be involved in the reduction of lactic acid in SC silage, because butyric acid was determined after $56 \mathrm{~d}$ of ensiling.

Lactic acid fermentation was enhanced in ensiled TMR. Unlike silages stored alone, lactic acid production was greater in SC compared with BG. Although fermentable sugars were increased by mixing with other feeds in the 2 TMR mixtures, yeasts might have grown as well as LAB in BGT silage. Yeast numbers were lower in SCT than BGT silage after $14 \mathrm{~d}$ of storage, suggesting that use of leguminous feed might have suppressed silage yeasts. Muck and O'Kiely (1992) reported that substances inhibiting yeasts may be produced during ensiling and retard aerobic spoilage in legume crop silage. Lactobacillus buchneri was found in BGT but not in SCT silage. However, the bacterium could not account for enhanced ethanol fermentation in BGT silage, because alcoholic fermentation was shown to be suppressed when L. buchneri was inoculated (Nishino et al., 2007).

Aerobic deterioration occurred promptly in fresh products and silages stored alone, confirming that silage fermentation was necessary to prevent spoilage in TMR silage. In conventional crop silages, yeast growth may trigger aerobic deterioration (Hara et al., 1979), and silages with yeast counts $>10^{5} \mathrm{cfu} / \mathrm{g}$ are prone to deteriorate after silo opening (McDonald et al., 1991). This could explain the instability of SC and BG silages, but not the stability of $14-d$ TMR silages. We have reported the same property of BGT silage: aerobic deterioration was not found even when a high yeast population survived (Nishino et al., 2004; Nishino and Hattori, 2007; Wang and Nishino, 2008). The SCT silage also showed high stability regardless of storage period, but it was unclear whether this stability was related to yeast counts. Yeast counts were $<10^{4} \mathrm{cfu} / \mathrm{g}$ in 14-d SCT silage, indicating that a low number of undesirable microorganisms might account for this stability. Even so, regardless of by-product type, prolonged ensiling could further improve the resistance to aerobic deterioration, because yeasts became almost or completely undetectable in 56-d TMR silages.

Culture-independent analysis is considered to have less bias than the conventional plate-count technique (Ercolini, 2004) and is increasingly being used to understand the make-up of the community of silage microorganisms (May et al., 2001; Yang et al., 2006). In this study, Weissella spp. and L. brevis were common in the 2 TMR silages, and L. buchneri was found exclusively in BGT silage. Weissella spp. were also found in fresh SC product, but $L$. brevis and L. buchneri were not 


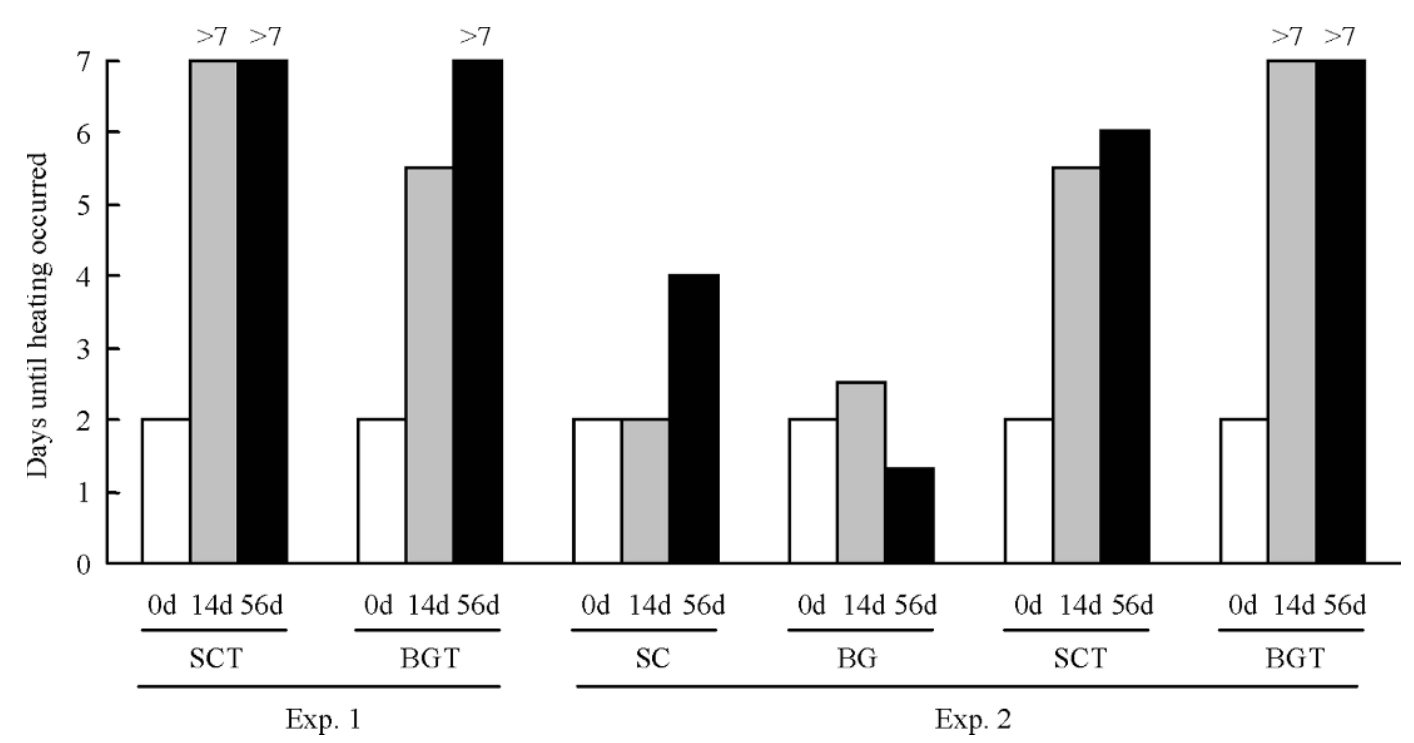

Figure 1. Aerobic stability of wet by-products and their TMR mixtures ensiled for 0,14 , and $56 \mathrm{~d}$. Changes in temperature were manually recorded at 12 - $\mathrm{h}$ intervals. $\mathrm{SC}=$ soybean curd residue; $\mathrm{BG}=$ brewers grains; $\mathrm{SCT}=\mathrm{SC}$-containing TMR silage; $\mathrm{BGT}=\mathrm{BG}-\mathrm{containing}$ TMR silage.

detected in either wet by-products or their TMR mixtures. These results suggest that heterofermentative $\mathrm{LAB}$ were predominant during fermentation of TMR silage, although there was no indication why this is the case. Lactobacillus buchneri has been shown to activate at later stages of ensiling (Driehuis et al. 1999), but in BGT silages LAB were detected from $14 \mathrm{~d}$ of ensiling. Because 1,2-propanediol, a specific metabolite of $L$. buchneri in silage, was increased by prolonged ensiling, the metabolic activity of $L$. buchneri in BGT silage, even if detected, may have been dormant in the early stages of ensiling. It is difficult to explain why $L$. buchneri emerged exclusively in BGT silage. However, in a subsequent experiment in which TMR silages were prepared with the same recipe as in this study, $1(3 \%)$ and $13(43 \%)$ isolates from 30 colonies were identified as $L$. buchneri in SCT and BGT silages, respectively (our unpublished data). Lactobacillus buchneri was also found in 56-d BG silage, suggesting that BG might contain factors or substances that could facilitate growth and survival of L. buchneri. In contrast, L. plantarum disappeared in TMR silages even though it was detected in material mixtures. Lactobacillus plantarum is one representative LAB frequently found in well-preserved silages (McDonald et al., 1991), but this homofermentative LAB might have difficulty surviving during fermentation of low-moisture TMR silages.

Although 3 heterofermentative LAB (Weissella spp., $L$. brevis, and L. buchneri) were assumed to be involved in silage stability, only $L$. buchneri was shown to actively suppress aerobic spoilage (Driehuis et al., 1999;
Weinberg et al., 1999; Ranjit and Kung, 2000). The stability of BGT silage could thus be accounted for by L. buchneri activity, but the stability of SCT silage is difficult to explain by the bacteria revealed by PCRDGGE. Neither Weissella spp. nor L. brevis improved stability when inoculated alone (Adesogan et al., 2003; Danner et al., 2003), and no metabolites were found that could inhibit the growth of yeasts and molds. There might have been synergism between Weissella spp. and L. brevis, but this would need to be confirmed by inoculation with aerobically unstable silages. In another experiment, we isolated Weissella spp. and L. brevis from stable TMR silages (our unpublished data), and further studies will be conducted to ascertain any possible synergistic effect.

\section{CONCLUSIONS}

Resistance to aerobic deterioration can be expected in TMR silages regardless of the wet by-products (SC and BG) formulated as principal ingredients. Lactic acid production was greater in SCT than in BGT silage, but resistance to spoilage appeared unrelated to the composition of fermentation products. Yeasts became undetectable when ensiling was prolonged, further improving stability in both SCT and BGT silages. Bacterial communities seemed to be established after $14 \mathrm{~d}$ of storage, although many indigenous bacteria did not survive, especially in TMR silages. Weissella spp. and L. brevis were common in stable TMR silages, whereas L. buchneri was detected only when BG was used. The 


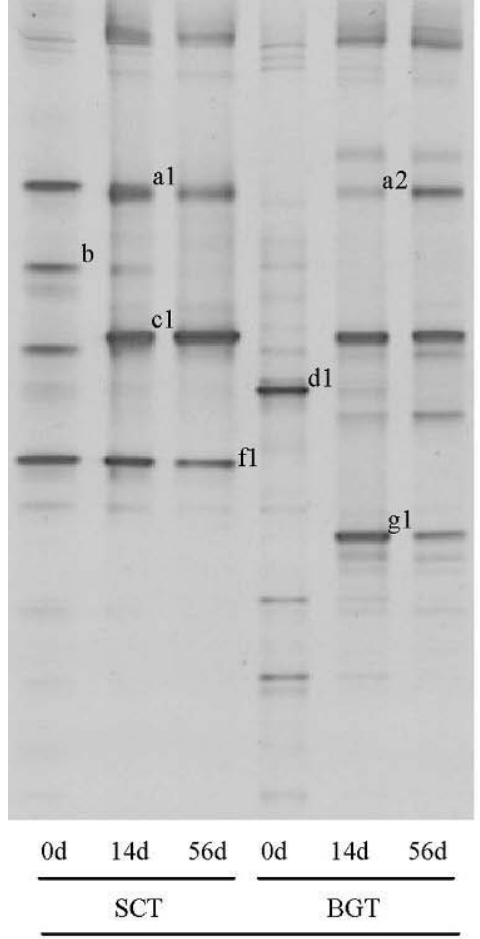

Exp. 1

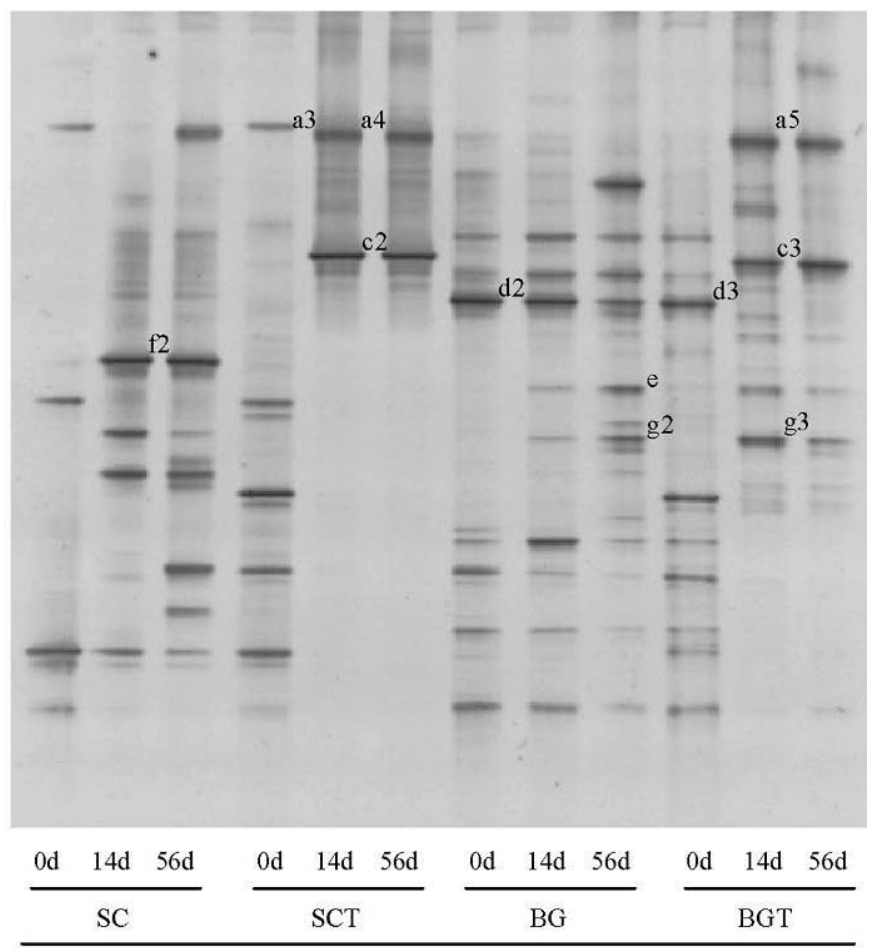

Exp. 2

Figure 2. Bacterial communities in wet by-products and their TMR mixtures ensiled for 0, 14, and 56 d. Denaturing gradient gel electrophoresis was carried out at a constant voltage of $150 \mathrm{~V}$ for $12 \mathrm{~h}$ at $60^{\circ} \mathrm{C}$, and several DNA bands were excised and sequenced. SC $=$ soybean curd residue; $\mathrm{BG}=$ brewers grains; $\mathrm{SCT}=\mathrm{SC}$-containing TMR silage; $\mathrm{BGT}=\mathrm{BG}$-containing TMR silage. a1 to a5 = Weissella spp.; $\mathrm{b}=$ Lactobacillus fermentum; $\mathrm{c} 1$ to $\mathrm{c} 3=$ Lactobacillus brevis; $\mathrm{d} 1$ to $\mathrm{d} 3=$ Lactobacillus plantarum; $\mathrm{e}=$ Pediococcus acidilactici; $\mathrm{f} 1$ to $\mathrm{f} 2=$ Streptococcus spp.; g1 to g3 = Lactobacillus buchneri.

results suggest that $L$. buchneri was involved in the stability of BGT silage, but it is not clear which bacteria were involved in the stability of SCT silage.

\section{ACKNOWLEDGMENTS}

A part of this study was supported by a Grant-in-Aid for Scientific Research (No. 19580311) from the Japan Society for the Promotion of Science, and by the Ministry of Agriculture, Forestry and Fishery of Japan (Integrated research for the fresh and delicious "Brand Nippon" agricultural-products).

\section{REFERENCES}

Abe, A. 2000. Food By-products and Total Mixed Ration Center. Snow Brand Milk Products Co. Ltd., Sapporo, Hokkaido, Japan.

Adesogan, A. T., M. B. Salawu, A. B. Ross, D. R. Davies, and A. E. Brooks. 2003. Effect of Lactobacillus buchneri, Lactobacillus fermentum, Leuconostoc mesenteroides inoculants, or a chemical additive on the fermentation, aerobic stability, and nutritive value of crimped wheat grains. J. Dairy Sci. 86:1789-1796.

Danner, H., M. Holzer, E. Mayrhuber, and R. Braun. 2003. Acetic acid increases stability of silage under aerobic conditions. Appl. Environ. Microbiol. 69:562-567.

Driehuis, F., S. J. W. H. Oude Elferink, and S. F. Spoelstra. 1999 Anaerobic lactic acid degradation during ensilage of whole crop maize inoculated with Lactobacillus buchneri inhibits yeast growth and improves aerobic stability. J. Appl. Microbiol. 87:583-594.

Ercolini, D. 2004. PCR-DGGE fingerprinting: Novel strategies for detection of microbes in food. J. Microbiol. Methods 56:297-314.

Hara, S., M. Itoh, and Y. Ohyama. 1979. Aerobic deterioration of silages. Changes in temperature, gas metabolism, heat production and microflora. Jpn. J. Zootech. Sci. 50:549-556.

Imai, A. 2001. Silage making and utilization of high moisture byproducts. 1. Significance of silage making for high-moisture byproducts. Grassl. Sci. 47:307-310.

Katayama, N. 2001. Silage making and utilization of high-moisture by-products. 2 . Nutritive characteristics and preservation method of by-products. Grassl. Sci. 47:311-317.

Lindgren, S. E., L. T. Axelsson, and R. F. McFeeters. 1990. Anaerobic L-lactate degradation by Lactobacillus plantarum. FEMS Microbiol. Lett. 66:209-214.

May, L. A., B. Smiley, and M. G. Schmidt. 2001. Comparative denaturing gradient gel electrophoresis analysis of fungal communities associated with whole plant corn silage. Can. J. Microbiol. 47:829-841.

McDonald, P., A. R. Henderson, and S. J. E. Heron. 1991. The Biochemistry of Silage. Chalcombe Publications, Welton, Lincoln, UK.

Muck, R., and P. O'Kiely. 1992. Aerobic deterioration of lucerne (Medicago sativa) and maize (Zea mays) silages-Effects of fermentation products. J. Sci. Food Agric. 59:145-149.

Nishino, N. 2006. Ensiled total mixed ration. A non-conventional silage supporting animal production in Japan. Pages 193-197 in Proc. 2nd China-Japan-Korea Sym. Grassl. Agric. Anim. Prod., Chinese Soc. Grassl. Sci., Lanzhou, China. 
Nishino, N., H. Harada, and E. Sakaguchi. 2003a. Evaluation of fermentation and aerobic stability of wet brewers grains ensiled alone or in combination with various feeds as a total mixed ration. J. Sci. Food Agric. 83:557-563.

Nishino, N., and H. Hattori. 2007. Resistance to aerobic deterioration of total mixed ration silage inoculated with and without homofermentative or heterofermentative lactic acid bacteria. J. Sci. Food Agric. 87:2420-2426.

Nishino, N., H. Hattori, and Y. Kishida. 2007. Alcoholic fermentation and its prevention by Lactobacillus buchneri in whole crop rice silage. Lett. Appl. Microbiol. 44:538-543.

Nishino, N., and E. Touno. 2005. Ensiling characteristics and aerobic stability of direct-cut and wilted grass silages inoculated with Lactobacillus casei or Lactobacillus buchneri. J. Sci. Food Agric. 85:1882-1888.

Nishino, N., H. Wada, M. Yoshida, and H. Shiota. 2004. Microbial counts, fermentation products, and aerobic stability of whole crop corn and a total mixed ration ensiled with and without inoculation of Lactobacillus casei or Lactobacillus buchneri. J. Dairy Sci. 87:2563-2570.

Nishino, N., M. Yoshida, H. Shiota, and E. Sakaguchi. 2003b. Accumulation of 1,2-propanediol and enhancement of aerobic stability in whole crop maize silage inoculated with Lactobacillus buchneri. J. Appl. Microbiol. 94:1-8.

Niwa, Y. 2001. Silage making and utilization of high-moisture byproducts. 4. Making silage from tofu cake and utilization. Grassl. Sci. 47:323-326.
Osaka, N. 2001. Silage making and utilization of high-moisture byproducts. 5. Silage making and utilization of apple pomace. Grassl. Sci. 47:327-331.

Oude Elferink, S. J. W. H., J. Krooneman, J. C. Gottschal, S. F. Spoelstra, F. Faber, and F. Driehuis. 2001. Anaerobic conversion of lactic acid to acetic acid and 1,2-propanediol by Lactobacillus buchneri. Appl. Environ. Microbiol. 67:125-132.

Pedro, M. S., S. Haruta, M. Hazaka, R. Shimada, C. Yoshida, K. Hiura, M. Ishii, and Y. Igarashi. 2001. Denaturing gradient gel electrophoresis analysis of microbial community from field-scale composer. J. Biosci. Bioeng. 91:159-165.

Ranjit, N. K., and L. Kung. 2000. The effect of Lactobacillus buchneri, Lactobacillus plantarum, or a chemical preservative on the fermentation and aerobic stability of corn silage. J. Dairy Sci. 83:526-535.

Schneider, R. M., J. H. Harrison, and K. A. Loney. 1995. The effects of bacterial inoculants, beet pulp, and propionic acid on ensiled wet brewers grains. J. Dairy Sci. 78:1096-1105.

Wang, F., and N. Nishino. 2008. Resistance to aerobic deterioration of total mixed ration silage: Effect of ration formulation, air infiltration and storage period on fermentation characteristics and aerobic stability. J. Sci. Food Agric. 88:133-140.

Weinberg, Z. G., G. Szakacs, G. Ashbell, and Y. Hen. 1999. The effect of Lactobacillus buchneri and L. plantarum, applied at ensiling, on the ensiling fermentation and aerobic stability of wheat and sorghum silages. J. Ind. Microbiol. Biotechnol. 23:218-222.

Yang, H. Y., X. F. Wang, J. B. Liu, L. J. Gao, M. Ishii, Y. Igarashi, and Z. J. Cui. 2006. Effects of water-soluble carbohydrate content of silage fermentation of wheat straw. J. Biosci. Bioeng. 101:232-237. 